University of Montana

ScholarWorks at University of Montana

Global Humanities and Religions Faculty

Publications

Global Humanities and Religions

Summer 2003

\title{
The Self Is Not Gendered: Sulabha's Debate with King Janaka
}

Ruth Vanita

University of Montana - Missoula, ruth.vanita@umontana.edu

Follow this and additional works at: https://scholarworks.umt.edu/libstudies_pubs

Part of the Feminist, Gender, and Sexuality Studies Commons

Let us know how access to this document benefits you.

\section{Recommended Citation}

Vanita, Ruth, "The Self Is Not Gendered: Sulabha's Debate with King Janaka" (2003). Global Humanities and Religions Faculty Publications. 1.

https://scholarworks.umt.edu/libstudies_pubs/1

This Article is brought to you for free and open access by the Global Humanities and Religions at ScholarWorks at University of Montana. It has been accepted for inclusion in Global Humanities and Religions Faculty Publications by an authorized administrator of ScholarWorks at University of Montana. For more information, please contact scholarworks@mso.umt.edu. 


\section{PROJECT MUSE}

\section{The Self Is Not Gendered: Sulabha's Debate with King Janaka}

\section{Ruth Vanita}

NWSA Journal, Volume 15, Number 2, Summer 2003, pp. 76-93 (Article)

Feminist

Published by The Johns Hopkins University Press

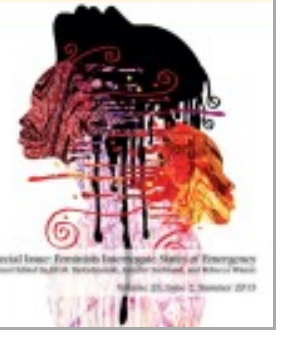

$\Rightarrow$ For additional information about this article

http://muse.jhu.edu/journals/ff/summary/v015/15.2vanita.html 


\title{
The Self Is Not Gendered: Sulabha's Debate with King Janaka
}

\author{
RUTH VANITA
}

This essay highlights the debate on women and gender in ancient Indian texts. Neither the popular nor the scholarly debate in modern India has paid sufficient attention to unmarried learned women in ancient Hindu texts. I examine the recurrent figure of Sulabha, a single woman and an intellectual-renunciant; I focus on her debate with philosopher-king Janaka in the epic Mahabharata. When Janaka uses anti-women arguments to critique Sulabha's unconventional behavior, Sulabha successfully establishes, on the basis of Hindu philosophical principles, that there is no essential difference between a man and a woman; she also demonstrates by her own example that a woman may achieve liberation by the same means as a man. In the same epic, a married woman wins her debate with a male sage, proving that even a woman following the conventional path of wifely devotion may equal or outdo a sage in wisdom and virtue.

Keywords: antiquity / gender / Hinduism / India / Mahabharata / Manusmriti / women

Who is Sulabha? Not many people, not even many Sanskrit scholars, recognize the name at once. She is a single woman, a learned renunciant, who, in the ancient epic, the Mahabharata, wins a debate with philosopher-king Janaka in the presence of eminent Brahman scholars. In this debate, Sulabha logically establishes that there is no essential difference between a man and a woman; she also demonstrates by her own example that a woman may achieve liberation by the same means as a man. Modern scholars of the Mahabharata have not paid much attention to this episode nor have feminist studies of ancient India given it the importance it deserves. ${ }^{1}$

\section{Modern Debates and Ancient Debates on Women}

In modern India, there is both a scholarly and a popular debate on women in ancient India. The popular wing of this debate suffers from an over emphasis on the law book, Manavadharmashastra or Manusmriti (circa first century CE). ${ }^{2}$ This emphasis is largely the legacy of British colonial administrators who, although they themselves were familiar with British common law, similar in some ways to the plethora of regional and com- 
munity customary laws prevailing amongst Hindus, decided to simplify their administrative tasks in India by compiling a digest of Hindu law based on translations of ancient treatises. To this end, the Bengal government published Sir William Jones's translation of Manusmriti in 1794.

The British justified their rule partly by attacking Indian social and political structures as iniquitous. This attack was primarily focused on Brahmans, hence the Manusmriti, which the Jones school of British administrators had magnified as symbolic of India's greatness, was declared a Brahmanical code and critiqued by the Macaulay school of administrators as symbolic of Indian society's backwardness.

Indian nationalists also took sides in this popular debate that still continues today. By selective quotation of some of Manu's dicta, such as his famous statement that the gods reside where women are honored, one group argues that the Manusmriti exalts women. By equally selective quotation of others of his dicta, such as his famous pronouncement that a woman should never be independent but should be under the protection of her father in youth, husband in adulthood, and son in old age, the other group argues that the Manusmriti is the source of gender oppression in India. Both groups agree in projecting Manu as the source of Hindu law. Thus, when admirers of Manu installed a statue of him in the precincts of the high court in Rajasthan, western India, his detractors protested, and burnt copies of the Manusmriti on 25 March 2000 (Kishwar 2000, 3).

Scholars agree that women's status declined from the Vedic period (c. $1500 \mathrm{BCE}$ ) to the period beginning about the first century CE. They differ, however, as to the extent of the decline. Some scholars, while agreeing that women in the epics and Puranas (the Puranas are sacred texts dedicated to various deities, composed between the second century BCE and the thirteenth century $\mathrm{CE}$ ) are generally subordinated to men, nevertheless claim that women are usually honored, have equal status to men in some spheres, and even more power than men in a few spheres. ${ }^{3}$

On the other hand, many Marxist and feminist critics argue that in this period woman "totally lost her human dignity" and "has been a chattel in India ever since the later Vedic times" (Bhattacharji 1994, 12, 89), and internalized her subordination to the extent that she did not protest or question it (Shah 1995, 72). These scholars view the dramatic rise of goddess worship and goddess theology from the Puranic period onwards as irrelevant to or even detrimental to women's status insofar as goddesses "do not suffer" and human women therefore cannot "feel empathy" with them (Bhattacharji 1994, 36). Some feminist scholars disagree with this view, and argue that to the extent that goddesses are seen as residing in women and girls, especially in Tantra and Shakta traditions, they do empower human women (Kinsley 1986; Gupta 2000).

In my view, modern debates do not sufficiently recognize the fact that there was an ongoing debate about women in ancient Hindu texts. 
The often seemingly self-contradictory pronouncements about women found in accretive ancient texts may reflect that debate, as do the varying interpretations of oral as well as written law. Both in pre-modern and in modern India, laws, especially written laws, are accessible to very few people and followed by even fewer, while most people are more likely to follow practices that are customary within their local castes and communities. However, these customary laws that vary widely from region to region and even village to village, are themselves always in dispute and open to varying interpretations, just as are written law codes. Hindu written law codes, from the Manusmriti through the British law codes to laws passed in independent India, always recognize the legal force and validity of custom. It is the bewildering plethora of interpretations of customary law that constitute the ongoing debate in the legal arena.

The varying versions and interpretations of the epic and Puranic stories that emerged at different times and places across the country and were accessible to most people through regular oral retellings and dramatic enactments also represent that debate. The Sulabha-Janaka debate in the canonical Sanskrit Mahabharata is an important example of that ongoing discussion. Janaka argues in favor of women's subordination, projecting a view found both in the Manusmriti and in many other texts, including the epics. ${ }^{4}$ Sulabha contests this view, basing her arguments on standard philosophical propositions.

Finally, I compare and contrast the Sulabha-Janaka debate with another similar debate in the Mahabharata - that between a married woman and the great sage Kaushika. Once again, the woman wins the debate and proves that while following the conventional path of wifely devotion, she is in fact more virtuous than he is. While many women could hope to imitate this model, fewer could aspire to be like Sulabha.

\section{The Single Woman as Intellectual}

I am interested in the figure of the single woman as intellectual-renunciant. This figure defies the dictum that a woman should always be under the protection of a man. How do the texts in which a figure like Sulabha appears justify her existence independent of men? How do they value her contribution to knowledge?

Behind the figure of the autonomous learned woman stands the figure of the autonomous goddess who presides over learning. Paradoxically, while the goddess of speech and of learning and the arts, Saraswati, generally represented without a consort, is very prominent in Indian popular culture, feminist scholars, both in the West and in India, have paid scarcely any attention to her. They have focused most of their attention on warrior mother goddesses such as Durga, Kali, and Chhinamasta. ${ }^{5}$ 
Concomitantly, feminist study of women's agency and resistance in the epics has focused not on single women but on the angry protests of wives, such as Draupadi's protest against her husband Yudhishthira's gambling her away, or Sita's protest against her husband Rama's unjust and harsh treatment of her after he rescues her from her abductor, Ravana. Less attention has been paid to women's participation in intellectual and philosophical conversation, even though both Sita and Draupadi engage in such conversations. Conversely, within mainstream Hindu tradition, Saraswati, who is widely worshiped in educational institutions and by those engaged in the arts, has been a symbol for education in general, and women's education in particular.

It is noteworthy that in the earliest Hindu sacred text, the Rigveda Samhita (c. 1500 BCE), the goddess Vak has no consort, and Saraswati too is worshiped without a consort in most traditions. On the other hand, the warrior goddesses are mostly incarnations of Parvati, consort of Shiva. Radha, who has received a lot of attention from scholars of Vaishnavism, is usually worshiped along with Krishna (Hawley and Wulff 1982). Feminist scholars' neglect of Saraswati is related to their focus on wives and mothers to the neglect of single women in ancient Indian texts.

Sulabha is a female ascetic or Rishika who is not a Brahman but a Kshatriya. Like the philosopher-king, Janaka, she belongs to the rulerwarrior community, not the priestly and scholarly community. Whereas Janaka is a husband and a king even while he pursues philosophical truth, Sulabha, by becoming an ascetic, opts out of social institutions like marriage, caste, and community.

It is important that neither Sulabha nor Janaka is just a character in a particular story, as is, for example, the Pandava hero Bhima. Both Sulabha and Janaka are symbolic figures who appear in different texts, in the Vedic as well as in the epic and Puranic periods. She represents the female scholar par excellence and he the scholar who is also a king. Thus the Saulabha Shakha (now lost) of the Rigveda Samhita is attributed to Sulabha. She appears again in the Kaushitaki Brahmana, in the list of revered teachers to whom salutations must be offered. Her most important appearance as a character is in the Shanti Parva of the epic Mahabharata, where she enters into a debate with King Janaka.

The Mahabharata, an accretive text whose date is disputed, was probably composed and compiled over a period of 800 years, between the fourth century вСЕ and the fourth century CE. Often termed the fifth Veda, it is the longest epic in the world, and tells the story of a battle between two sets of cousins. This story is submerged in a plethora of other stories, debates, and discussions. Even though few Hindus have read the entire epic, the stories of the Mahabharata are widely disseminated through song, drama, and now cinema and television. Figures and events from these stories have become both idiomatic and figurative in Indian lan- 
guages. The Mahabharata contains the BhagvadGita, the dialog between Krishna and Arjuna that is among the most widely read Hindu sacred texts.

\section{Debate and Dialog in Hindu Texts}

Debate is the single most important organizing principle in ancient Hindu texts. It may take the form of structured question and answer, friendly discussion and dialog, or formal shastrartha (debate) between rival schools of thought. In the Mahabharata it occurs most often as conversation. In fact, the whole epic is structured as a series of conversations encased one within the other. These conversations take place between ancestors and descendants, male friends (Krishna and Arjuna), male and female friends (Krishna and Draupadi), female friends (Draupadi and Satyabhama), enemies, siblings, parents and children, husbands and wives, gods and humans, human and non-human animals, servants and masters, teachers and pupils, and strangers who encounter one another by chance.

A wide spectrum of issues, ranging from vegetarianism to justice to gender to the means of attaining liberation from rebirth, are discussed at length, and powerful arguments are advanced on several sides of each question. While many different answers are presented, one of them usually, but not always, emerges as the correct answer. This does not mean, however, that the other answers are completely invalidated.

Perhaps the most famous debate between a woman and a man in an ancient Hindu text is that between Gargi and Yajnavalkya, which takes place in the presence of King Janaka, in the Brihadaranyaka Upanishad. Feminist scholars usually cite this debate as an example of the silencing of women in patriarchal society because the debate ends with Yajnavalkya silencing Gargi by telling her that if she asks any more questions her head will fall off.

Conversely, both the debates here examined-between King Janaka and the female ascetic Sulabha, and between the married woman and the sage Kaushika-end with the silencing of the male participant. The Sulabha-Janaka debate takes place in the Shanti Parva section of the epic Mahabharata. The Shanti Parva was composed later than many other sections of the epic, but is philosophically well integrated with the rest of the epic.

The Sulabha-Janaka debate may reflect a debate between different schools of Hindu philosophy. While it is framed as a debate regarding the relative superiority of action and renunciation as paths to liberation (moksha) from the cycle of rebirth, this is also a debate about gender, specifically whether a woman can be autonomous, can be a man's intellectual equal or superior, and can attain emancipation independently. 
Although the text may be influenced by Buddhism and/or may be responding to Buddhism, Sulabha is not represented as a Buddhist. While Buddhism introduced organized female asceticism (despite the initial reluctance of Buddha to allow women into the monastic order), Hindu female ascetics do appear in many ancient texts. Sulabha is of particular interest because her asceticism is not undertaken in the capacity of a hermit's wife, as is that of other female hermits in the Mahabharata. She is a single woman who is an ascetic in her own right. Nor is she part of any organized order or monastery, as Buddhist nuns were. We are explicitly told that she wanders over the earth. As such, she represents one type or ideal of Hindu asceticism, here embodied in a female. This is important, because many modern commentators who see Buddhism as more liberatory for women than Hinduism tend to think that renunciation was available to Buddhist but not to Hindu women.

Hindu texts in general tend to represent women as embodiments of action, and to reserve renunciation for men. In the Vedic texts, the primal principle of action or nature, Prakriti, is gendered female, while Purusha, or the consciousness that witnesses action while remaining detached from it, is gendered male. This gendering of primal principles is of course not coterminous with human males and females, since each human individual partakes of both Purusha and Prakriti. Nevertheless, that gendering does influence Hindu ideas of gender roles, with the man being perceived as more inclined to spiritual knowledge and the woman as more inclined to earthly action. Both scholarly and popular wisdom subscribe to the idea that the primary path to emancipation for a Hindu woman is devotion to her husband. Several normative characters in the Mahabharata actually state this to be the case.

The figure of Sulabha, however, shows that the Mahabharata, like Hindu thought in general, is by no means unified on this issue. The equation of women with action is not a necessary one. It is possible and desirable for a Hindu woman to attain emancipation by renunciation. The Atman (Self/Spirit) is gendered neuter in Sanskrit, and is the same in all beings. This premise is basic to Sulabha's sophisticated argument regarding the irrelevance of gender to emancipation or to the particular path taken by an individual.

\section{Context of the Debate}

The Shanti Parva is, as its name indicates, about peace in its widest sense. More specifically, this long section of the Mahabharata occurs as a conversation between the eldest of the five Pandava brothers, King Yudhishthira, and his great-uncle Bhishma. The conversation occurs after the battle has been won by the Pandavas. 
Bhishma is the son of the river goddess Ganga. His name literally means "the terrible" because of the awe-inspiring vow of lifelong celibacy he took as a young man to please his father, and he is the epitome of the virtuous and wise person. He participates in the battle in a selfless manner because his vow of celibacy was accompanied by renunciation of the kingship in favor of his younger brother. Though childless, he functions in the text as a father figure to all his nephews. Fatally wounded during the battle, he does not die because he has the power to die only when he chooses. He lies on a bed of arrows that he considers the only fit bed for a warrior.

After the battle, the Pandavas, King Yudhishthira, and their allies go to visit Bhishma. Yudhishthira, who throughout the text represents the virtuous wisdom-seeker, questions Bhishma about how to rule as a king and how to achieve liberation from the cycle of rebirth. His questions and Bhishma's answers compose the Shanti Parva. The title suggests that the answers, if acted upon, establish peace after war, in the individual and in society. After Bhishma has spoken about the various aspects of kingship and rule, Yudhishthira asks Bhishma how to attain liberation from the cycle of death and rebirth. This section within the Shanti Parva is known as Mokshadharma Parva.

At one point in this section, Yudhishthira asks how one can avoid old age and death. Bhishma tells him that King Janaka had once asked his guru, the Rishi (ascetic) named Panchashikha, this question and was told that old age and death cannot be avoided. All human relationships are transient like life itself. The only way to escape death is to escape birth as well, that is, to be freed from the cycle of rebirth. Yudhishthira, himself a husband, father, and king, then asks whether it is possible to attain emancipation from the cycle of rebirth without abandoning the domestic way of life.

In response, Bhishma recounts the story of Janaka and Sulabha. King Janaka, in ancient Hindu texts, is the epitome of the philosopher king, a perfectly wise ruler who is also a sage. Bhishma says that a female mendicant and yogini, Sulabha, while wandering over the earth, hears from many ascetics that Janaka is devoted to the religion of emancipation so she decides to meet him. Using her Yoga powers, she assumes the form of a faultlessly beautiful young woman and presents herself to Janaka as a mendicant.

It is significant that she assumes both forms (of a woman and a mendicant), that is, neither form is integral to or inseparable from her self. This connects to the philosophical point she makes later, that all forms are transitory and apparent, not permanent or innate to the Atman. The king is filled with wonder at her delicate form. He welcomes her as an honored guest, seats her on an excellent seat, and offers her water to wash her feet and good food to refresh herself. Bhishma continues: 
Doubting whether Janaka had succeeded in attaining to Emancipation, . . . Sulabha, endued [endowed] with Yoga-power, entered the understanding of the king by her own understanding. Restraining, by means of the rays of light that emanated from her own eyes, the rays issuing from the eyes of the king, the lady, desirous of ascertaining the truth, bound up King Janaka with Yoga bonds. (Ganguly 1973, X:57)

The word "sanchodayishyanti," used for her action, indicates that she questions or examines him not in words but internally by her Yoga powers. Janaka reacts with hostility to this examination. As a sage and a king, Janaka has reached the pinnacle of two types of male achievement. Sulabha's internal questioning of him suggests that her Yoga powers equal or surpass his own. Janaka is unused to being challenged or tested in this way, but what particularly irks him is that a woman dares to test him as an equal.

\section{Janaka's Conventional View of Women}

Interrupting Sulabha's questioning, Janaka addresses her at length. After stating that he respects Sulabha and desires to know her thoroughly, Janaka demands to know who she is, whose she is, where she has come from, and where she is going. He declares that he is free from the vanity of kingship, and he is the only person who can discourse to her on emancipation. He emphasizes his high spiritual lineage by pointing out that he acquired his knowledge from his guru, Panchashikha of Parasara's race. Janaka claims that even though he is a king and is married, he has attained knowledge of the Atman (knowledge of oneness of one's Atman with the universal Atman), and is free from all attachments. Though alive, he is emancipated. He is free from love for his wife or hatred of his enemies. In terms very close to those of Krishna's instructions in the BhagvadGita, he states that he views a lump of gold and a clod of earth as equal, and a person who wounds him as equal to a person who honors him.

He then makes the bold claim that he is superior to all ascetics who have renounced the world. His argument in this regard is that an ascetic's renunciation of the world may be only apparent, not genuine, while conversely, a king's attachment to and enjoyment of the world may be apparent, not genuine. He then aggressively tries to demonstrate that Sulabha is not a genuine renunciant. His argument is not entirely logical for it proceeds in the following manner: I am superior to all renunciants; renunciants may be attached to the world while kings may be unattached to the world. You, Sulabha (because you are a woman), are actually attached to the world, while I, the king, am not attached to the world. The only prima facie true proposition here is the second-most people would agree 
and many texts demonstrate that some ascetics may be fake while some householders may be emancipated. However, Janaka then proceeds to demonstrate his third proposition by appealing to conventional notions of gender roles, while his first proposition remains unproved. His bullying tone and his masculinist attitude to Sulabha seem quite inappropriate for a person who claims to be detached from the world and therefore from social prejudices.

He begins his argument regarding Sulabha by telling her that her behavior does not correspond to the ascetic way of life. She is delicate, shapely, and youthful, and he therefore doubts that she has subdued her senses. The implication here is that a young and beautiful woman is incapable of overcoming her desires for sensual and sexual pleasure.

He then goes on to say that her act of entering into him by Yoga powers is sinful. He equates this act with sexual union, and in fact, a type of rape, as he had not made any gesture inviting her to enter into him. Assuming that this is a physical union between a woman and a man, he points out that it is wrong in at least four ways. First, since she is a Brahman (he assumes that since she is an ascetic, she must belong to the Brahman community) while he is a Kshatriya, a union between them would cause an inappropriate mixture of two varnas (literally, colors; figuratively, the four groups into which society is broadly divided). Second, since she is an ascetic and he is a householder, a union between them would cause an inappropriate mixture of two ways of life. Third, since neither of them knows to which gotra (exogamous clans, marriage between members of which is forbidden as incestuous) the other belongs, it is possible that the union is an unnatural one between members of the same gotra. Fourth, if she is married, the union is sinful (interestingly, his being married would not make his union with her sinful, as a man may have many sexual relationships, but a woman only one). Finally, since he does not desire her, her union with him is like poison.

He then goes on to speculate that she may have perpetrated all these sinful acts because of "ignorance or perverted intelligence" (Ganguly 1973, X:61), but in any case, by trying to display her superiority to men, she has shown herself to be a wicked woman. He wonders whether she is the agent of some rival king. This speculation indicates that he is unable to conceive of an autonomous female agent and so thinks she must be merely an instrument, acting at the behest of a male. Janaka concludes this diatribe by stating that the power of kings consists in sovereignty, the power of Brahmans in the Vedas, and the power of women in their beauty, youth, and marital blessedness, therefore one should never try to deceive a king, a Brahman, or a good wife. He then reiterates his questions regarding who she is, whose she is, and where she has come from. 


\section{Sulabha's Philosophical Response}

Bhishma comments that Sulabha replies in words more beautiful than her person. Sulabha begins her response with a discourse on speech. She gives a learned account of the verbal faults and the faults of judgment that can occur in speech, and says that her reply will be rational, clear, and not prompted by emotions like desire, wrath, fear, or shame. She argues that only a speaker who is able to communicate his meaning to the hearer is worthy of the title of speaker.

Sulabha then proceeds to address the king's questions-who she is, whose she is, and where she comes from. Her answer is: "As lac and wood, as grains of dust and drops of water, exist commingled when brought together, even so are the existences of all creatures" (Ganguly 1973, X: $65)$. This is a statement of the philosophical position that the primal elements are the same in all bodies and beings, and the same consciousness pervades all existents, therefore if Janaka were truly knowledgeable, he would not ask her who she is, as he would know that she and he are essentially the same. To regard his own self as different from the self of other beings is to lack wisdom.

Sulabha then proceeds to elaborate on the nature of the senses, the consciousness, and the principles of existence. Her erudition is evident both in this disquisition and in her earlier one on the nature of speech. She describes how the fetus is formed from the process of insemination and develops in the womb where it acquires a sex. She emphasizes the fact that at every stage, "the constituent elements of the body ... undergo change every moment in every creature" (Ganguly 1973, X:66). Particles of the body are constantly born and constantly die, but these changes are so minute that they cannot be observed, just as one cannot perceive the changes in the flame of a lamp. Given this state of constant change and flux in individual identity, "who then has come whence or not whence, or whose is it or whose is it not" (X:67)? Identity, being in flux, cannot be fixed or possessed. ${ }^{6}$

This argument demonstrates that sex difference is not an essential difference. To consider it essential is to be deluded. The king's emphasis on sex difference shows that he is not liberated, as he claims to be. If he were, he would see no difference between himself and others: "If it is true thou hast, O king, been freed from the knowledge of duality that says-this is mine and this other is not mine-then what use is there with such questions as, Who art thou, whose art thou and whence does thou come" (Ganguly 1973, X:67).

She points out that a king who acts toward others as enemies or allies is not emancipated. Here she gestures toward his hostility to her. A king who does not look with an equal eye on the weak and the strong is not 
emancipated. Janaka views her, a woman, as not equal to men. This shows his lack of emancipation.

Sulabha proceeds to point out how little power or control a king actually has. Despite all his wealth and property, he can use only a limited number of things and consume a limited number of objects. He is always dependent on others, such as his counselors, and his life is circumscribed by the demands of others. He can sleep and eat only when permitted and often cannot gratify his desires because he has to transact the business of the state. She also shows that a king cannot be truly detached from the world. He is mistrustful of others, and a prey to fear, grief, alarm, insomnia, and unsubstantial happiness. The king shares the attachments and problems of all householders. Other men are kings in their own homes and suffer similar losses and victories on a smaller scale.

Finally, Sulabha demonstrates that her intellectual union with the king is not sinful. She has not touched him physically and it is a misinterpretation to consider this a sexual union. It was improper for him to proclaim before his court that she had entered into union with him. The intellectual communion between them was a private matter and by making it public and describing it in sexual terms, he has disrespected himself, her, and his courtiers.

Sulabha declares that her body is different from Janaka's but there is no difference between her Self or Spirit (Atman) and his Self or any other person's Self. Janaka confused body and Self/Spirit when he considered the union of selves to be a bodily union. A wise person knows that the Self has no real connection with his/her own body, let alone the bodies of others. Her assessment is that while Janaka is not fully immersed in the domestic mode of life, he has not yet attained emancipation. He is midway between the two, pretending to be emancipated.

She tells Janaka that she belongs to a royal family and no husband could be found fit for her. She wanders over the earth alone, practicing asceticism. She tells him that she is in fact a Kshatriya, just like him. Once again, Janaka has betrayed his prejudiced assumptions by assuming that all ascetics are Brahmans or that only a Brahman can be an ascetic. She says that she came to meet him only to discuss emancipation with him. She points out that nothing she has said is meant to glorify herself or to humiliate opponents, since an emancipated person, being tranquil, speaks only to express the truth and never to engage in intellectual competition or to win a dispute. Bhishma comments that Janaka is unable to answer Sulabha's reasoned words. This indicates that her arguments are unanswerable. At the end of this debate, Janaka is silenced by truth, unlike Gargi, who in her debate with Yajnavalkya, is silenced by terror tactics. 


\section{Janaka Versus Sulabha: Arrogance Versus Dignity}

Most modern discussions of the Mahabharata do not mention Sulabha. One scholar, who mentions her in passing, dismisses her as "just a maverick and nothing more" (Shah 1995, 68). While there is no doubt that Sulabha, as a learned single woman, is an exception in the Mahabharata, nevertheless the recurrent presence of this figure in several texts and her triumph in this text do show that celibacy and learning were conceived of as options for the few women who might manage to define themselves as exceptional.

Much more important, however, is the content of the debate, wherein Sulabha provides philosophical justification for equality and non-differentiation between women and men. Similar statements regarding non-differentiation made elsewhere in the Mahabharata, for example, in the BhagvadGita (the man of steady wisdom sees no difference between a Brahman and an elephant, a cow and a cow-eater), are not transposed from perception (what the wise man sees) to social action (how the wise man treats these beings, although many stories in the epics do suggest that the wise man would treat all beings with respect). Sulabha, however, tells Janaka not just that he was wrong to see her and himself as different because of gender, but also that he acted wrongly when he followed social conventions regarding gender and reproached her for ignoring those conventions.

Janaka and his arguments regarding gender are easily recognizable and conventional ones. First, he defines a woman by her ties to men, and if he cannot do so, he becomes very uncomfortable. Hence his anxiety to know "whose" Sulabha is. As in the oft-quoted dictum of Manu, Janaka believes that a woman always belongs to some man-father, husband, or son. If she does not belong to one man, she is then a wicked or loose woman who cannot be trusted as she may unite with any man, activated by lust, or may act as a spy for a king and deceive other kings.

Second, Janaka doubts that a beautiful young woman is capable of subduing her senses-this misogynist doubt is in consonance with the many pronouncements regarding the uncontrollable nature of women's sexual desires found in ancient and medieval texts, both Indian and European. Since he defines women as sexual, not intellectual or spiritual, beings (he claims that a woman's power consists only in youth, beauty, and marital blessedness), it follows that he cannot conceive of any communion or union between a woman and a man that is not sexual. Hence his allegation that by entering into inner union with him through Yoga, Sulabha has in fact entered into physical union with him. Here, his thinking is in consonance with that of the many stories in the epics and Puranas of temptresses seducing men who have renounced desire. 
Janaka arrogantly imagines that since he has achieved emancipation, but Sulabha as an unmarried young woman is incapable of doing so, her only aim could be to destroy him by seducing him. Janaka cannot conceive of even a seductress acting entirely on her own initiative. Indeed, the temptresses in the epic and Puranic stories rarely act on their own initiative; they are usually sent by the ascetic's rivals (often the gods) to divest a man of his Yoga powers. Hence Janaka suspects that a rival king has sent Sulabha to ruin him.

Third, Janaka displays throughout an arrogance that is unbecoming to an emancipated or wise person and also to a good king. He shows none of the humility of good kings like Rama and Yudhishthira, and makes the outrageous claim that he is superior to all ascetics, a type of claim usually made by demons such as Bakasura just before their fall. The hostility he displays towards Sulabha represents the specifically male dimension of his arrogance. Even though she is his guest, he insults her, accusing her of wickedness and evildoing.

Sulabha's response is remarkable for its dignity. Her analysis of the faults of speech demonstrates (without stating it) that Janaka's speech is faulty because it is impelled by anger, not reason. She also indirectly critiques his hostility to her when she points out that an emancipated king would view the weak and the strong with an equal eye.

Her reasoned response to Janaka's argument is very important, because here the text provides an answer to the popular view that gender altogether defines a woman's role and her dharma. Sulabha's argument is grounded in basic Hindu philosophical premises, with which few orthodox Hindus would disagree, and this is its strength. Her primary arguments may be summarized thus:

1. The body is gendered but the Atman (universal Self/Spirit) is not gendered.

2. The body acquires its gender at a certain stage in the womb, and the body changes constantly, so even the body is not always gendered in the same way, that is, even bodily gender is not a fixed or static thing.

3. The Atman is one and the same in all beings, regardless of the body's gender.

4. The Atman is neither the property of anyone nor under the control of anyone, and the Atman does not really act.

Following from these philosophical premises are her important secondary arguments that have practical implications for women's social status:

1. Since the same Atman animates both women and men, women are capable of pursuing the same paths as men.

2. A truly wise person, who has realized the oneness of the Atman, will not try to judge anyone, including any woman, by caste or marital status. 
3. The Atman is not the property of anyone, so a truly wise person realizes that to ask a woman to whom she belongs is meaningless.

4. Since the Atman is one, intellectual or spiritual communion/union between any two persons, including a man and a woman, is not the same as physical union, and is not wrong.

\section{Wifely Devotion as Agency}

The debate between the married woman and Kaushika in the Mahabharata is at the other end of the spectrum but establishes a similar thesis. In this story, the ascetic Kaushika goes on his rounds asking for alms, and gets annoyed when a devoted housewife keeps him waiting while she serves her husband. When he reproaches her despite her apology, she replies with dignity, and gives him an extended scholarly lecture wherein she demonstrates that a true Brahman is not one who merely knows the scriptures but rather one who has overcome anger and "who looketh upon all equal unto himself" (Ganguly 1973, II:424). This point is the same as Sulabha's-a truly wise person sees no difference between a man and a woman.

She also claims that the path of virtue she follows is that of devotion to her husband whom she regards as the highest god. While this may be read as a glorification of subservience, it is worth noting the element of agency that the woman claims when she says "I practise that virtue which consists in serving my husband" (Ganguly 1973, II:424). Unlike Sulabha, she follows the conventional path of most women, yet this path has led her to acquire greater virtue than the sage.

The housewife dares to tell the great Brahman sage, "I think, O holy one, that thou dost not know what virtue in reality is" (II:425). She then sends him to a fowler for further instruction. The Brahman realizes that her analysis of his failings is accurate and that her reproof will be advantageous to him. The fowler, who belongs to a very low caste and is engaged in a profession (killing living creatures) regarded as despicable, turns out to be a highly meritorious person "with senses under complete control," who is completely devoted to his parents (II:425). He considers his parents to be his highest deities and serves them night and day. The next several chapters are occupied with the fowler's learned discourse, as he teaches the Brahman the nature of true virtue and detachment.

The idea that emerges is that an apparently lowly and unimportant way of life may also be a site for self-realization. Like Janaka, Kaushika has acquired knowledge of the Vedas and other scriptures but has not acquired the virtue that comes from right practice. This right practice may be that of asceticism as in Sulabha's case, or that of a layperson's selfless life, as in the case of the housewife and the fowler. 
The housewife's statement of her own practice is suggestive of agency, choice, self-conscious practice, and the dignity arising therefrom. This practice puts her in a position to critique and reprove a powerful man who is a major philosophical figure. As compared to Sulabha, the housewife is not independent, and, from our point of view today, appears to be in an unfortunate position. Yet, the text attempts to cultivate an understanding of all social positions-whether that of king, sage or fowler, housewife or ascetic, male or female-as ephemeral, and the pursuit of self-realization-whether by the path of devotion, action, or asceticism-as permanently valuable.

\section{Hindu Philosophy and Women's Choices}

Sulabha's victory in the debate (demonstrated by Janaka's inability to answer her) justifies her own choices in life (not to marry, to wander the world alone, to seek emancipation by the same path as men), and her actions (to enter into public debate with a famous man, to enter into Yogic union with him). Although she is an exception in the Mahabharata, it is important to note that she is a recurrent figure in several texts widely separated by time, and is thus an emblematic figure, like Janaka. Her choices act as a model and her arguments provide a philosophical justification, within Hinduism, for any woman to make unconventional choices. Her arguments are not restricted to women of any particular caste or class; since they are based on the oneness of the universal Atman, they apply to any woman anywhere.

Medieval women mystics, like the famous poet and fifteenth-century princess, Mirabai, also a Kshatriya renunciant, thus emerge in the context of medieval devotion and also in the context of an older tradition that makes space for women. Before the modern period, social conditions prevented women in most societies throughout the world (not just in India) from staying single and pursuing intellectual and spiritual paths in an autonomous manner; it is important that when exceptional women have made such choices in India, they have usually found some acceptance, not just on the fringes, but even in the mainstream of society. Hindu philosophy easily lends itself to arguments such as those of Sulabha.

While many Hindu texts, especially law books, and Hindu philosophy itself are often used to justify inequality and non-freedom, Hindu texts and Hindu philosophical arguments have also frequently been used, both in pre-modern and in modern India, to legitimize egalitarianism and freedom. For example, in the nineteenth century, Ramabai (1858-1922), a young widow educated by her father, demonstrated her knowledge of Sanskrit and began to work to educate women. A conclave of Brahmans gave 
her the title "Pandita" (feminine version of Pandit, meaning a scholar). She retained this title throughout her life, even after her conversion to Christianity, and is still known today as Pandita Ramabai Saraswati.

The representation of a female figure winning a debate, which is a battle of words, arguably works as a more imitable model than the representation of a female winning a battle with weapons. Both in texts and in life, many more females engage in debate and conversation than in warfare. Kali's or Durga's miraculous victories in battle may inspire women to fight for justice or to take revenge on oppressors; Sulabha's logical victory in debate has the potential to make the oppressor see the folly of his thinking.

\section{Focusing on Debate}

When we focus on the dynamic debates regarding gender that flourish in ancient Hindu texts we help combat the stereotype of these texts as either monolithically justifying the subordination of women or as monolithically honoring women. This endeavor enables us to study how these pre-modern textual debates have reflected and enabled ongoing non-textual debates as well as many different societal trends and practices in Indian societies through the ages. Finally, it also helps us understand that modern Indian debates about gender have a history that is not traceable to Euro-American feminism alone, a history that defines the questions and poses the answers both similarly to and differently from the way the questions and answers have been posited in Euro-American debates about gender.

I would like to thank the anonymous NWSA Journal readers whose reports helped me to refine my argument and improve this essay.

Ruth Vanita is Professor of Liberal Studies and Women's Studies at the University of Montana. She taught at Delhi University for many years, and was founding co-editor of Manushi: A Journal About Women and Society. She is the author of Sappho and the Virgin Mary: Same-Sex Love and the English Literary Imagination, co-author of Same-Sex Love in India: Readings in Literature and History, co-editor of In Search of Answers: Indian Women's Voices from Manushi, and editor of Queering India. She has received an ACLS fellowship to work towards a book on long-term same-sex unions and marriages in pre-modern and modern Indian socio-political, religious, legal, and literary contexts. Correspondence should be sent to Vanita at Liberal Studies Program, University of Montana, Missoula, MT 59812; rvanita@selway.umt.edu. 


\section{Notes}

1. Even Vidyalankar (1984) fails to discuss Sulabha in her study specifically of the Shanti Parva, the section of the Mahabharata in which the debate occurs.

2. Kishwar (2000) makes a similar point, but takes it much further than I am willing to take it. She argues, for example, that Manu, the putative author of the Manusmriti (who may well be an amalgam of many authors), would have supported Kishwar's right to compose her own Smriti (sacred remembered text) if "he" lived today.

3. This is broadly the approach taken by Altekar in his pioneering work, The Position of Women in Hindu Civilization (1956) and also by Bader (1925). Bhavalkar (1999) belongs to the same school.

4. For example, the Shanti Parva, in which the Sulabha-Janaka debate occurs, also contains about one third of the precepts of the Manusmriti, repeated in near-identical form.

5. Pintchman (1994) argues that Indian women have been unable to draw on these goddesses as models. She suggests, though, that Kali could be an empowering model (213). McDermott (1996) shows how Kali is the most congenial of all Hindu goddesses both to scholars and to feminists in the West. In Hawley and Wulff's anthology, Devi: The Goddesses of India (1996), there are essays on consort goddesses like Radha and warrior goddesses like Kali, but no essay on Saraswati. Kinsley (1986) is an exception, as he studies each individual goddess, including Saraswati, in some detail. Interestingly, major mainstream Indian publishing houses have chosen the names of the goddess of learning, Saraswati and Sharada, as names for their enterprises, while the Indian feminist publishing house is called Kali.

6. A point made in different ways by many Western philosophers as well, from Heraclitus to Montaigne and David Hume, and most recently by postmodernists.

\section{References}

Altekar, A.S. 1956. The Position of Women in Hindu Civilization. Delhi, India: Motilal Banarsidass.

Bader, Clarisse. (1925) 2000. Women in Ancient India. Reprint. London: Routledge.

Bhattacharji, Sukumari. 1994. Women and Society in Ancient India. Calcutta, India: Basumati Corporation Ltd.

Bhavalkar, Vanamala. 1999. Woman in the Mahabharata. Delhi, India: Sharada Publishing House. 
Ganguly, Kisari Mohan, ed. and trans. (1883-1896) 1973. The Mahabharata of Krishna Dwaipayana Vyasa. $3^{\text {rd }}$ ed. New Delhi, India: Munshiram Manoharlal.

Gupta, Samjukta Gombrich. 2000. "The Goddess, Women, and the Rituals in Hinduism." In Faces of the Feminine in Ancient, Medieval, and Modern India, ed. Mandakranta Bose, 87-123. Delhi, India: Oxford University Press.

Hawley, John Stratton, and Donna M. Wulff, eds. 1996. Devi: Goddesses of India. Berkeley: University of California Press.

- 1982. The Divine Consort: Radha and the Goddesses of India. Delhi, India: Motilal Banarsidass.

Kinsley, David. 1986. Hindu Goddesses: Visions of the Divine Feminine in the Hindu Religious Tradition. Berkeley: University of California Press.

Kishwar, Madhu. 2000. "From Manusmriti to Madhusmriti: Flagellating a Mythical Enemy." Manushi (117):3-8.

McDermott, Rachel Fell. 1996. "The Western Kali." In Devi: Goddesses of India, eds. John Stratton Hawley and Donna Marie Wulff, 281-313. Berkeley: University of California Press.

Pintchman, Tracy. 1994. The Rise of the Goddess in the Hindu Tradition. Albany: State University of New York Press.

Shah, Shalini. 1995. The Making of Womanhood: Gender Relations in the Mahabharata. Delhi, India: Manohar Publications.

Vidyalankar, Sumedha. 1984. Mahabharata mein Shanti Parva ka Alochnatmak Adhyayan (A Critical Study of Shanti Parva in Mahabharata). Delhi, India: Eastern Book Linkers. 